UDC 616.1-616-06-07-08

https://doi.org/10.26641/2307-0404.2020.4.221220

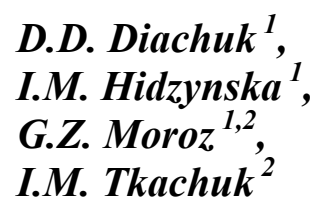

\title{
CURRENT APPROACHES TO MEDICAL CARE OPTIMIZATION FOR PATIENTS WITH MULTIMORBIDITY
}

\author{
State Institution of Sciences "Research and Practical Center of Preventive and Clinical Medicine" \\ State Administrative Department ${ }^{l}$ \\ Verchnia str., 5, Kyiv, 01014, Ukraine \\ Ukrainian Military Medical Academy ${ }^{2}$ \\ Moskovska str., 45/1, Kyiv, 01015, Ukraine \\ Державна наукова установа "Науково-практичний центр профілактичної та клінічної медицини" \\ Державного управління справами ${ }^{l}$ \\ (дир. - член-кор. НАМН України, д. мед. н. Д.Д. Дячук) \\ вул. Верхня, 5, Київ, 01014 Украӥна \\ Українська військово-медична академія ${ }^{2}$ \\ (нач. -д. мед. н., проф., полковник мед. служби В.Л. Савицький) \\ вул. Московська, 45/1, Київ, 01015, Україна \\ e-mail:moroz_galina@i.ua
}

\author{
Цитування: Медичні перспективи. 2020. T. 25, № 4. С. 4-11 \\ Cited: Medicni perspektivi. 2020;25(4):4-11
}

Key words: multimorbidity, patient-centered care, guidelines

Ключові слова: мультиморбідність, пацієнт-орієнтовані втручання, клінічні настанови

Ключевые слова: мультиморбиднисть, пациент-ориентированные вмешательства, клинические руководства

\begin{abstract}
Current approaches to medical care optimization for patients with multimorbidity. Diachuk D.D., Hidzynska I.M., Moroz G.Z., Tkachuk I.M. Scientific interest to the problem of multimorbidity is increasing due to the increase of the number of such patients. The aim of this work was to analyze and summarize current approaches to optimizing care for patients with multimorbidity and the results of their implementation in clinical practice. Since the beginning of this century, a number of documents have been created by WHO, government agencies and professional medical societies to improve medical care to patients with multimorbidity. The evidential basis of the effectiveness of the majority of the proposed measures based primarily on expert consensus. In 2016 NICE has published a clinical guideline NG56 "Multimorbidity: clinical assessment and management», WHO - a monograph «Multimorbidity: Technical Series on Safer Primary Care». In 2017 NICE has published a quality standard - Quality Standard №153 "Multimorbidity». The strategy of improvement of medical care for patients with multimorbidity is directly related to the patient-centered approach formation, which includes comprehensive assessment of the patient's condition. The main component of medical care is the definition of a realistic goal of medical intervention according to patient's preferences, and making the choice of the optimal amount of diagnostic, treatment, and preventive measures, which can lead to the desired goal. A number of studies (the 3D randomized controlled trial, the MultiCare AGENDA, the SPPiRE study, the WestGem study etc.) have being conducted to evaluate the effectiveness of implementing proposed approaches in clinical practice. The results of the studies and meta-analysis do not provide conclusive evidence of the medical and economic effectiveness of their implementation at the presentstage. Improving the outcomes of medical care to patients with multimorbidity involves conducting further clinical trials that can provide evidence to determine the list of most effective interventions for clinical practice.
\end{abstract}

Реферат. Сучасні підходи до оптимізації медичної допомоги пацієнтам з мультиморбідністю. Дячук Д.Д., Гідзинська І.М., Мороз Г.3., Ткачук І.М. Науковий інтерес до проблеми мультиморбідності зростає через збільшення кількості таких пацієнтів. Метою ичього дослідження було проведення аналізу й узагальнення сучасних підходів до оптимізації медичної допомоги хворим з мультиморбідністю та результатів їх впровадження у клінічну практику. 3 початку иьього століття ВООЗ, державні установи та професійні медичні товариства створили ряд документів для вдосконалення медичної допомоги пацієнтам з мультиморбідністю. Доказова база ефективності більшості запропонованих заходів в основному трунтується на консенсусі експертів. У 2016 рочі NICE опублікував клінічні настанови NG56 «Мультиморбідність: клінічна оцінка та управління», ВООЗ - монографію «Мультиморбідність: Технічна серія щзодо безпечної первинної допомоги». У 2017 рочі NICE опублікував стандарт якості - Стандарт якості №153 «Мультиморбідність». Стратегія вдосконалення медичної допомоги пацієнтам з мультиморбідністю безпосередньо пов'язана із формуванням підходу, орієнтованого на пацієнта, щуо включає комплексну оцінку стану пацієнта. Основним компонентом 
медичної допомоги є визначення реалістичної мети медичного втручання, відповідно до індивідуальних пріоритетів пацієнта, та вибір оптимального обсягу діагностичних, лікувальних та профілактичних заходів, які можуть привести до бажаної мети. Для оијнки ефективності впровадження запропонованих підходів у клінічну практику було проведено ряд досліджень (3D-рандомізоване контрольоване дослідження, МиltiСаге AGENDA, SPPiRE, дослідження WestGem та ін.). Результати проведених досліджень та метааналізів на ией час не надали переконливих доказів щчодо клінічної та економічної ефективності впровадження запропонованих підходів у клінічну практику. Поліпшення результатів медичної допомоги пацієнтам з мультиморбідністю передбачає подальше проведення клінічних досліджень, які зможуть надати доказову базу для визначення переліку найбільш ефективних підходів для клінічної практики.

Improving medical care for patients with multimorbidity is an important priority of modern medicine [16]. According to WHO information, in developed countries, almost $25 \%$ of the entire population had more than one long-term condition [19]. More than $50 \%$ of older adults in the USA have three or more chronic diseases [11]. Multimorbidity is associated with a lot of adverse outcomes, including deterioration in overall health, disability, poorer quality of life $(\mathrm{QoL})$, higher rates of adverse effects of treatment and greater use of healthcare resources [20,9]. Multimorbidity can occur in adults of any age, but its prevalence more often increases in older adults [23]. Population aging is a significant burden for the 21 st century - in 2050, the proportion of individuals $\geq 65$ years will account for $20 \%$ of the world population, and the number of persons $\geq 80$ years will reach 447 million [10]. Another important aspect is how to use evidencebased medicine recommendations for the treatment of patients with multimorbidity. Clinical guidelines usually focus on the management of a single disease or condition, and people with multimorbidity are often excluded from the trials that generate the underlying evidence for these guidelines. Application of clinical guidelines for a patient with multimorbidity means that this patient faces significant burden of treatment, regarding multiples appointments, examinations, analyzes and consultations, competing demands for self-management and polypharmacy [3]. Therefore, there is a need to develop recommendations for the care of people with multimorbidity.

Despite the problems with the evidence base, over the last decade, such recommendations have been developed in different countries, namely, the USA, the Great Britain and Germany. They are mainly based on expert consensus. In 2010-2012 two papers were developed in the USA -one of them - «Multiple Chronic Conditions - A Strategic Framework: Optimum Health and Quality of Life for Individuals with Multiple Chronic Conditions» - by the U.S. Department of Health and Human Services [21], and the other - «Guiding principles for the care of older adults with multimorbidity: an approach for clinicians» - by the American Geriatrics Society
[11]. In 2016 NICE has published a clinical guideline NG56 «Multimorbidity: clinical assessment and management» [17] and WHO - a monograph «Multimorbidity: Technical Series on Safer Primary Care» [19]. In 2017 the German College of General Practice and Family Medicine (DEGAM) proposed an algorithm on multimorbidity (so-called "metaalgorithm") for primary care services [4]. A number of studies has been conducted to evaluate the effectiveness of implementing proposed approaches into clinical practice [7].

The aim of this work was to analyze and summarize current approaches to optimizing care for patients with multimorbidity and the results of their implementation in clinical practice.

\section{MATERIALS AND METHODS OF RESEARCH}

The analysis and the generalization of Clinical guidelines and recommendations for management of the patients with multimorbidity were carried out. The results of their implementation into clinical practice are summarized. Methods were used: systematic approach, biblio-semantic, analytical [29].

\section{RESULTS AND DISCUSSION}

Current approaches for healthcare delivery to patients with multimorbidity are based on the models of care in chronic conditions [14]. Management of such people require a transformation of healthcare - from a system that is essentially reactive, responding mainly when a person is sick to one that is proactive, holistic and preventive. One of widely known healthcare approach to long-term conditions - the Chronic Care Model (CCM) - was first developed by The MacColl Institute for Healthcare Innovation (USA) in the late 1990s [6]. It is a framework for coordinated services that enables patients with long-term conditions and clinicians to work together with the objective to achieve optimal medical care. The CCM takes, as its starting point, the active involvement of patients in developing their own care plans through a shared decisionmaking process with clinicians. Other important items of the management of patients with chronic conditions are supported self-management, coordinated care, prevention, early diagnosis and 
intervention, emotional, psychological and practical support at follow-up [2].The patient-centered approach is one of the most important interventions in terms of positive health-related outcomes for patients with chronic diseases [31]. This component of CCM is widely used in multimorbidity management guidance, including the Ariadne principles, that have been developed by a team of experts GP from Europe, North America, and Australia in 2012 [27]. The Ariadne principles underscore that, when using clinical guidelines recommendations for patients with multiple chronic conditions, the main component of medical care is the definition of a realistic goal of medical intervention according to patient's preferences, and making the choice of the optimal amount of diagnostic, treatment, and preventive measures, which can lead to the desired goal [27].

One of the first official documents, dedicated to the problem of multimorbidity, was the paper of the U.S. Department of Health and Human Services «Multiple Chronic Conditions - A Strategic Framework: Optimum Health and Quality of Life for Individuals with Multiple Chronic Conditions» [21], which has being published in 2010. This document underscores the importance of patient-centered multidisciplinary care, namely the coordination of the work of physicians from different health care units, and the communication and collaboration across health care facilities. The Department emphasizes the importance of preventive measures for the control of multiple chronic illnesses at the national level - «A cornerstone of our nation's approach to chronic diseases must be to prevent their occurrence» - by controlling risk factors that are common to most such diseases, and promoting a healthy lifestyle.

In 2012 the «Guiding principles for the care of older adults with multimorbidity: an approach for clinicians: American Geriatrics Society Expert Panel on the Care of Older Adults with Multimorbidity» have being published [11]. This is a consensus document which presents recommendations to the care of older people with multimorbidity in primary setting and describes guiding principles for the clinical management of this population. The main component of the proposed approach is patient's involvement in the clinical decision-making process and the identification of patients' health priorities. The scope of care is determined by optimizing the positive effect, minimizing the undesirable effects and improving the QoL. One of this work goals is to facilitate the development and growth of an evidence base by which clinicians can make sound care decisions for this population, including the testing of better processes for decision-making.
The NICE clinical guideline «Multimorbidity: clinical assessment and management» (NG56) was created by the multidisciplinary Guideline Development Group (GDG) in 2016 with the use of available evidences based on the results of randomized trials, observational and qualitative studies (including diagnostic, prognostic, and questionnaire performance studies), the Ariadne principles, the American Geriatrics Association recommendations, the joint AHA/ACC and the US Department of Health and Human Services strategies on optimization the application of clinical practice guidelines in people with cardiovascular disease and comorbid conditions (2014), and a number of other previously published NICE guidelines, especially, "Medicines adherence" (2009); "Medicines optimization" (2014); "Depression in adults with a chronic physical health problem" (2009) [17]. The GDG evaluated the efficacy of complex interventions and components of care models aimed at improving outcomes for people with multimorbidity such as multidisciplinary care, holistic assessment, self-management, coordinated care plans, format of encounters. The NG56 defines the guiding principles of multimorbidity management, with a special consideration to aspects, such as medical counseling, which should be based on patient-centered care principle and aimed at improving the QoL by reducing treatment burden, adverse events, and unplanned care. The essential component of medical care is a tailored holistic approach, which includes a careful assessment of the patient's individual priorities, values and goals, the interaction of the person's health conditions and their treatments, their impact on the QoL, and arrangement of an individualized management plan. Other important components - continuity of care from prevention and self-care through primary and secondary care to more specialized services, implementation of measures aimed to improve communication between patient and health professionals, determination of the responsible for coordinating patient's care and follow-up. The determination of the coordinator of the medical care process is a very important step. It may be a health or social care professional, but usually this activity is assigned to the primary care physician. The importance of NICE clinical guideline NG56 is that it confirms the prevalence of multimorbidity, affirms the need to take a patient-centered care and holistic approach to the evaluation of patient's conditions and provides guidance about key principles of medical care [15].

In 2017 NICE has published a quality standard Quality Standard №153 «Multimorbidity» 2017, which relies on NG56 [18]. The quality standard includes statement on shared decision-making and 
coordination of care. According to the standard, indicators of quality of care of patient with multimorbidity are:

- Identification of adults with multimorbidity by the GP (such people should be identified proactively using patient's health records);

- Providing opportunities for patients with multimorbidity to discuss their health priorities and the desired result of medical care and establish an individualized management plan;

- Determining patient's awareness of the person responsible for coordinating their care;

- Providing opportunities for patients to discuss their management plan, review medicines and other treatments, and consider whether any medication can be stopped or changed [18].

NICE quality standard describes high-priority areas for improving the quality of care for patients with multimorbidity, and is designed to support the measurement of improvement [18].

WHO evaluated the association of multimorbidity with the safety of primary care in a monograph within a technical series in 2016 [19]. This monograph was based on the advices of experts in the field who proposed examples of strategies that worked well around the world, and practical suggestions. WHO experts draw attention to the role of primary care physicians and comprehensive primary care system for improving the safety of primary care in the management of people with multimorbidity [19]. WHO suggested, that multimorbidity need to be integrated into the medical education system, and primary care physicians should to be trained as "expert generalists", including postgraduate training. In order to make save primary care physicians are advised to avoid complex treatment regimens, and not to tend to treat all diagnosed diseases. Care should be proactive and anticipatory and include preventive measures for those at risk of developing multiple conditions, but medical staff should wisely evaluate the number of risk factors to be corrected [19]. Another important aspect highlighted in the WHO monograph - continuity of care and interaction of primary care system with specialized and social services. Enhanced communication and coordination across different healthcare system levels, including through the use of electronic health records and clinical registries that allow a longitudinal evaluation of the management strategies and clinical outcomes, is of great importance.

In 2017 an Expert group of the German College of General Practice and Family Medicine (DEGAM) developed a comprehensive algorithm (meta-algorithm) for primary care encounters of patients with multimorbidity [4]. This algorithm reflects the logic of a GP consultation of such patients regarding decision-making situations, communication needs and priorities. As previous papers the DEGAM`s meta-algorithm underscores the importance of patient-centred care and holistic assessment of patient's conditions which should determine the physician`s activity in multimorbidity. Contrary to simple, symptom-oriented algorithms, this approach illustrates a superordinate process that permanently keeps the entire patient in view. To prepare the implementation of the meta-algorithm, it was planned to be embedded into the DEGAM's multimorbidity guideline in 2020 .

Thus, the improvement of medical care for patients with multimorbidity is directly related to the formation of a patient-centered approach, which includes comprehensive assessment of the patient's condition, taking into account both clinical parameters and a complex of related factors, coordination of the treatment plans - regarding the intensity of treatment, its impact on the functional status, day-to-day activities and wellbeing - and enhancing the patient-physician relationship (therapeutic alliance). Such strategy is broadly supported by medical staff, patients, and caregivers. The delivery of goal-concordant care was proposed as a quality indicator and rated by an expert panel as the most important outcome measure of scientific studies on multimorbidity $[12,30]$. But currently we do not have generalization method for assessing the concordance of care provided to patients with their goals: patient's goals may not to be established or haven't been documented, they may change over time, assessment of the compliance of the intervention with established goals by the patient and the doctor may be different.

Determining the effectiveness of implementing a patient-centered approach in the treatment of patients with multimorbidity has been the subject of a number of studies, including those conducted using evidence-based medicine. Coulter A. \& al. [24] analyzed the results of 19 studies published in the Cochrane Database of Systematic Reviews by 2013, and concluded that, compared to usual care, personalized approach leads to a certain improvement of health status and the patient's selfmanagement capabilities. These effects were increasing in the case of more comprehensive, more intensive, and better integrated into routine care interventions [24]. Another study, evaluating a patient-centered approach to multimorbidity in general practice - the $3 \mathrm{D}$ randomized controlled trial - was conducted in the UK [1]. Although the study was planned before 2016, its strategy was in line with the NG56 recommendations [17] and includes 
an emphasis on patient-centered care, explicit agenda setting, self-management support, shared decision-making and care planning. The results demonstrated, that the proposed approach did not lead to a significant improvement of the QoL and doesn't decrease the number of medications prescribed, but patients did say that "care was more joined up and better at treating them as a whole person" [1]. In addition, 3D model implementation was provided at little additional costs.

Kastner M. et al. [7] evaluated randomized controlled trials on multimorbidity published from 1990 to December 2017 in any language. Analyses showed that older adults with diabetes and either depression or cardiovascular disease, or with coexistence of chronic obstructive pulmonary disease and heart failure, can benefit from carecoordination strategies to lower $\mathrm{HbAlc}$, reduce depressive symptoms and improve health-related functional status.

A number of other studies of multimorbidity are currently underway: the MultiCare AGENDA [20], the SPPiRE study [26], the WestGem study [13], the DREAMeR-study [8], the PRIMUM pilot study, studies on using telemedicine and other technologies for physician-patient communication. Their results are mostly modest, only few demonstrated a statistically significant effect on the QoL or the drug-related problems [13]. At the present we do not yet have reliable information on the clinical and economic effectiveness of the proposed approaches to the management of multimorbidity; however, ongoing researches are providing more and more data. The patient-centered care model is increasingly being used both in clinical practice and scientific research. An important issue remains the training of medical staff on multimorbidity and the implementation of practical suggestions to coordination of care delivery, improving interaction and communication between healthcare professionals across medical settings [1,7]. An additional item that can potentially reduce the burden of multimorbidity is the risk factor's control and prevention of chronic diseases development. According to forecasts [25] between 2015 and 2035 in the UK, multi-morbidity prevalence is estimated to increase, the proportion with $4+$ diseases almost doubling (2015: 9.8\%; 2035: 17.0\%). Multimorbidity prevalence in incoming cohorts aged 6574 years will rise (2015: 45.7\%; 2035: 52.8\%). The authors of the study advocate for a new focus on prevention of, and appropriate and efficient service provision for those with, complex multimorbidity.

\section{CONCLUSIONS}

Effective treatment of people with multiple chronic illnesses is one of the most complex problems facing the current healthcare system. A number of studies has been conducted to evaluate the effectiveness of implementing some certain approaches to healthcare delivery for patients with multiple chronic conditions into clinical practice, however their results are ambiguous, and the majority of them have a low level of evidence. Improving the outcomes of medical care to patients with multimorbidity involves conducting clinical trials that can provide evidence to determine the list of most effective interventions for further clinical practice. Thus, in the modern world, a new model of care is emerging that goes beyond traditional approaches to treating specific diseases.

Conflict of interests. The authors declare no conflict of interest.

\section{REFERENCES}

1. Salisbury C, Man M-S, Chaplin K, Mann C, Bower $\mathrm{P}$, Brookes $\mathrm{S}$, et al. A patient-centred intervention to improve the management of multimorbidity in general practice: the 3D RCT. Health Services and Delivery Research. 2019;7(5).

doi: https://doi.org/10.3310/hsdr07050

2. Coulter A, Kramer G, Warren T and Salisbury C. Building the House of Care for people with long-term conditions: the foundation of the House of Care framework. British Journal of General Practice. 2016;66(645):e288-e290. doi: https://doi.org/10.3399/bjgp16X684745

3. Millar E, Dowell A, Lawrenson R, Mangin D, Sarfati D. Clinical guidelines: what happens when people have multiple conditions? The New Zealand Medical Journal [Internet]. 2018;131(1472):73-81. Available from: https://www.nzma.org.nz/journal-articles/clinical-guidelineswhat-happens-when-people-have-multiple-conditions

4. Muche-Borowski C, Lühmann D, Schäfer I, Mundt R, Wagner H-O, Scherer M. Development of a meta-algorithm for guiding primary care encounters for patients with multimorbidity using evidence-based and case-based guideline development methodology. BMJ Open. 2017;7:e015478.

doi: https://doi.org/10.1136/bmjopen-2016-015478

5. Muth C, Harder S, Uhlmann L, Rochon J, Fullerton B, Güthlin C, et al. Effectiveness of a complex intervention on Prioritising Multimedication in Multimorbidity (PRIMUM) inprimarycare: resultsof a pragmatic cluster randomised controlledtrial. BMJ Open. 2018;8(2):e017740. doi: https://doi.org/10.1136/bmjopen-2017-017740 
6. Davy C, Bleasel J, Liu H, Tchan M, Ponniah S, Brown A. Effectiveness of chronic care models: opportunities for improving healthcare practice and health outcomes: a systematic review. BMC Health Services Research. 2015;15:194.

doi: https://doi.org/10.1186/s12913-015-0854-8

7. Kastner M, Cardoso R, Lai Y, Treister V, Hamid JS, Hayden L, et al. Effectiveness of interventions for managing multiple high-burden chronic diseases in older adults: a systematic review and metaanalysis. CMAJ. 2018;190(34):e1004-12.

doi: https://doi.org/10.1503/cmaj.171391

8. Verdoorn S, Kwint HF, Blom JW, Gussekloo J, Bouvy ML. Effects of a clinical medication review focused on personal goals, quality of life, and health problems in older persons with polypharmacy: A randomised controlled trial (DREAMeR-study). PLoS Medicine. 2019;16(5):e1002798.

doi: https://doi.org/10.1371/journal.pmed.1002798

9. Millar E, Stanley J, Gurney J, Stairmand J, Davies $\mathrm{C}$, Semper $\mathrm{K}$, et al. Effect of multimorbidity on health service utilisation and health care experiences Journal of Primary Health Care. 2018;10(1):44-53. doi: https://doi.org/10.1071/HC17074

10. Dzau VJ, Inouye SK, Rowe JW, Finkelman E, Yamada T. Enabling Healthful Aging for All - The National Academy of Medicine Grand Challenge in Healthy Longevity. NEJM. 2019;381(18):1699-701. doi: https://doi.org/10.1056/NEJMp1912298

11. Guiding principles for the care of older adults with multimorbidity: an approach for clinicians: American Geriatrics Society Expert Panel on the Care of Older Adults with Multimorbidity. Journal of the American Geriatrics Society. 2012;60(10):e1-e25. doi: https://doi.org/10.1111/j.1532-5415.2012.04188.x

12. Halpern S.D. Goal-Concordant Care - Searching for the Holy Grail. NEJM. 2019;381(17):1603-6. doi: https://doi.org/10.1056/NEJMp1908153

13. Köberlein-Neu J, Mennemann H, Hamacher S, Waltering I, Jaehde U, Schaffert C, Rose O. Interprofessional medication management in patients with multiple morbidities - a cluster-randomized trial (the WestGem study). Deutsches Arzteblatt International. 2016;113(44):741-8. doi: https://doi.org/10.3238/arztebl.2016.0741

14. Smith SM, Wallace E, O'Dowd T, Fortin M. Interventions for improving outcomes in patients with multimorbidity in primary care and community settings. The Cochrane Database of Systematic Reviews. 2016;14(3):CD006560. doi: https://doi.org/10.1002/14651858.CD006560.pub3

15. Kernick D, Chew-Graham C. A, O’Flynn N. Clinical assessment and management of multimorbidity: NICE guideline. British Journal of General Practice. 2017;67(658):235-6.

doi: https://doi.org/10.3399/bjgp17X690857

16. Multimorbidity: a priority for global health research. The Academy of Medical Sciences. [Internet]; 2018. Available from: https://acmedsci.ac.uk/policy/policyprojects/multimorbidity

17. Multimorbidity: clinical assessment and management. Institute for Health and Care Excellence: NG56. London; 2016.
18. Multimorbidity: Quality Standard. National Institute for Health and Care Excellence: QS153. [Internet]; 2017. Available from: https://www.nice.org.uk/guidance/qs153

19. Multimorbidity: Technical Series on Safer Primary Care. Geneva; World Health Organization. [Internet]; 2016 Available from: https://apps.who.int/iris/bitstream/handle/10665/252275/9 789241511650-eng.pdf? sequence $=1$

20. Navickas R, Petric VK, Feigl AB, Seychell M. Multimorbidity: what do we know? What should we do? Journal of Comorbidity. 2016;6(1):4-11. doi: https://doi.org/10.15256/joc.2016.6.72

21. Multiple Chronic Conditions - A Strategic Framework: Optimum Health and Quality of Life for Individuals with Multiple Chronic Conditions / U.S. Department of Health and Human Services. Washington, DC, 2010. Available from: https://www.hhs.gov/sites/default/files/ash/initiatives/mcc /mcc framework.pdf

22. Schäfer I, Kaduszkiewicz H, Mellert C, Löffler C, Mortsiefer A, Ernst A, et al. Narrative medicine-based intervention in primary care to reduce polypharmacy: results from the cluster-randomised controlled trial MultiCare AGENDA. BMJ Open. 2018;8(1):e017653.

23. Zemedikun DT, Gray LJ, Khunti K, Davies MJ, Dhalwani NN. Patterns of multimorbidity in middle-aged and older adults: an analysis of the UK Biobank data. Mayo Clinic Proceeding. 2018;93(7):857-66. doi: https://doi.org/10.1016/j.mayocp.2018.02.012

24. Coulter A, Entwistle VA, Eccles A, Ryan S, Shepperd S, Perera R. Personalized care planning for adults with chronic or long-term health conditions. The Cochrane Database of Systematic Reviews. 2015;3. doi: https://doi.org/10.1002/14651858.CD010523.pub2

25. Kingston A, Robinson L, Booth H, Knapp M, Jagger C. Projections of multi-morbidity in the older population in England to 2035: estimates from the Population Ageingand Care Simulation (PACSim) model. Age and Ageing. 2018;47(3):374-80.

doi: https://doi.org/10.1093/ageing/afx201

26. McCarthy C, Clyne B, Corrigan D, Boland F, Wallace E, Moriarty F, et al. Supporting prescribing in older people with multimorbidity and significant polypharmacy in primary care (SPPiRE): a cluster randomised controlled trial protocol and pilot. Implementation Science. 2017;12:99. doi: https://doi.org/10.1186/s13012-017-0629-1

27. Muth C, van den Akker, M, Blom J, Mallen CD, Rochon J, Schellevis FG, et al. The Ariadne principles: how to handle multimorbidity in primary care consultations. BMC Medicine. 2014;12:223. doi: https://doi.org/10.1186/s12916-014-0223-1

28. Valdivieso B, García-Sempere A, Sanfélix-Gimeno G, Faubel R, Librero J, Soriano E, Peiró S. The effect of telehealth, telephone support or usual care on quality of life, mortality and healthcare utilization in elderly high-risk patients with multiple chronic conditions. A prospective study. Medicina clinica. 2018;151(8):308-14.

doi: https://doi.org/10.1016/j.medcli.2018.03.013 
29. Hasanpoor E, Hallajzadeh J, Siraneh Y, Hasanzadeh E, Haghgoshayie E. Using the Methodology of Systematic Review of Reviews for Evidence-Based Medicine. Ethiop J Health Sci. 2019;29(6):775-8. doi: https://doi.org/10.4314/ejhs.v29i6.15

30. Dzau VJ, McClellan MB, McGinnis JM, Burke SP, Coye MJ, Diaz A, et al. Vital directions for health and health care: priorities from a National Academy of
Medicine in itiative. JAMA. 2017;317(14):1461-70. doi: https://doi.org/10.1001/jama.2017.1964

31. Poitras M-E, Maltais M-E, Bestard-Denommé L, Stewart M, Fortin M. What are the effective elements in patient-centered and multimorbidity care? A scoping review. BMC Health Services Research. 2018;18:446. doi: https://doi.org/10.1186/s12913-018-3213-8

\section{СПИСОК ЛІТЕРАТУРИ}

1. A patient-centred intervention to improve the management of multimorbidity in general practice: the 3D RCT / C. Salisbury et al. Health Services and Delivery Research. 2019. Vol. 7, No. 5.

DOI: https://doi.org/10.3310/hsdr07050

2. Building the House of Care for people with longterm conditions: the foundation of the House of Care framework / A. Coulteret et al. Br. Journal of General Practice. 2016. Vol. 66, No. 645. P. e288-e290. DOI: https://doi.org/10.3399/bjgp16X684745

3. Clinical guidelines: what happens when people have multiple conditions? / E. Millar et al. The New Zealand Medical Journal. 2018. Vol. 131. No. 1472. P. 73-81. URL: https://www.nzma.org.nz/journal-articles/clinicalguidelines-what-happens-when-people-have-multipleconditions

4. Development of a meta-algorithm for guiding primary care encounters for patients with multimorbidity using evidence-based and case-based guideline development methodology / C. Muche-Borowski et al. BMJ Open. 2017. Vol. 7. P. e015478. DOI: https://doi.org/10.1136/bmjopen-2016-015478

5. Effectiveness of a complex intervention on Prioritising Multimedication in Multimorbidity (PRIMUM) inprimarycare: resultsof a pragmatic cluster randomised controlledtrial / C. Muthet et al. BMJ Open. 2018. Vol. 8, No. 2. P. e017740.

DOI: https://doi.org/10.1136/bmjopen-2017-017740

6. Effectiveness of chronic care models: opportunities for improving healthcare practice and health outcomes: a systematic review / C. Davy et al. BMC Health Services Research. 2015. Vol. 15. P. 194. DOI: https://doi.org/10.1186/s12913-015-0854-8

7. Effectiveness of interventions for managing multiple high-burden chronic diseases in older adults: a systematic review and metaanalysis / M. Kastner et al. CMAJ. 2018. Vol. 190. P. e1004-1012. DOI: https://doi.org/10.1503/cmaj.171391

8. Effects of a clinical medication review focused on personal goals, quality of life, and health problems in older persons with polypharmacy: A randomised controlled trial (DREAMeR-study) / S.Verdoornet et al. PLoS Medicine. 2019. Vol. 16, No. 5. P. e1002798. DOI: https://doi.org/10.1371/journal.pmed.1002798

9. Effect of multimorbidity on health service utilisation and health care experiences / E. Millar et al. Journal of Primary Health Care. 2018. Vol. 10, No. 1. P. 44-53. DOI: https://doi.org/10.1071/HC17074
10. Enabling Healthful Aging for All - The National Academy of Medicine Grand Challenge in Healthy Longevity / V. J. Dzau et al. NEJM. 2019. Vol. 381, No. 18. P. 1699-1701.

DOI: https://doi.org/10.1056/NEJMp1912298

11. Guiding principles for the care of older adults with multimorbidity: an approach for clinicians / American Geriatrics Society Expert Panel on the Care of Older Adults with Multimorbidity. Journal of the American Geriatrics Society. 2012. Vol. 60. P. e1-25. DOI: https://doi.org/10.1111/j.1532-5415.2012.04188.x

12. Halpern S. D. Goal-Concordant Care - Searching for the Holy Grail. NEJM. 2019. Vol. 381, No. 17. P. 1603-1606.

DOI: https://doi.org/10.1056/NEJMp1908153

13. Interprofessional medication management in patients with multiple morbidities - a cluster-randomized trial (the WestGem study) / J. Köberlein-Neu et al. Deutsches Arzteblatt International. 2016. Vol. 113, No. 44. P. 741-748.

DOI: https://doi.org/10.3238/arztebl.2016.0741

14. Interventions for improving outcomes in patients with multimorbidity in primary care and community settings / S. M. Smithet et al. The Cochrane Database of Systematic Reviews. 2016. Vol. 14, No. 3. CD006560. DOI: https://doi.org/10.1002/14651858.CD006560.pub3

15. Kernick D., Chew-Graham C. A., O'Flynn N. Clinical assessment and management of multimorbidity: NICE guideline. Br. Journal of General Practice. 2017. Vol. 658, No. 67. P. 235-236.

DOI: https://doi.org/10.3399/bjgp17X690857

16. Multimorbidity: a priority for global health research / The Academy of Medical Sciences. April, 2018. URL: https://acmedsci.ac.uk/policy/policy-

projects/multimorbidity

17. Multimorbidity: clinical assessment and management / Institute for Health and Care Excellence: NG56. London, 2016.

URL: https://www.nice.org.uk/guidance/ng56

18. Multimorbidity: Quality Standard / National Institute for Health and Care Excellence: QS153, 2017. URL:https://www.nice.org.uk/guidance/qs153

19. Multimorbidity: Technical Series on Safer Primary Care / Geneva: World Health Organization, 2016. Licence: CC BY-NC-SA3.0 IGO.

URL: https://apps.who.int/iris/bitstream/handle/10665/25 2275/9789241511650-eng.pdf?sequence $=1$ 
20. Multimorbidity: what do we know? What should we do? / R. Navickas et al. Journal of Comorbidity. 2016. Vol. 6, No. 1. P. 4-11.

DOI: https://doi.org/10.15256/joc.2016.6.72

21. Multiple Chronic Conditions - A Strategic Framework: Optimum Health and Quality of Life for Individuals with Multiple Chronic Conditions / U.S. Department of Health and Human Services. Washington, DC, 2010. URL: https://www.hhs.gov/sites/default/files/ash/initiativ es/mcc/mcc_framework.pdf

22. Narrative medicine-based intervention in primary care to reduce polypharmacy: results from the clusterrandomised controlled trial MultiCare AGENDA / I. Schäferet et al. BMJ Open. 2018. Vol. 8, No. 1. P. e017653.

23. Patterns of multimorbidity in middle-aged and older adults: an analysis of the UK Biobank data / D. T. Zemedikunet et al. Mayo Clinic Proceeding. 2018. Vol. 93, No. 7. P. 857-866.

DOI: https://doi.org/10.1016/j.mayocp.2018.02.012

24. Personalized care planning for adults with chronic or long-term health conditions / A. Coulter et al. The Cochrane Database of Systematic Reviews. 2015. Vol. 3. DOI: https://doi.org/10.1002/14651858.CD010523.pub2

25. Projections of multi-morbidity in the older population in England to 2035: estimates from the Population Ageingand Care Simulation (PACSim) model / A. Kingston et al. Age and Ageing. 2018. Vol. 47, No. 3. P. 374-380. DOI: https://doi.org/10.1093/ageing/afx201
26. Supporting prescribing in older people with multimorbidity and significant polypharmacy in primary care (SPPiRE): a cluster randomised controlled trial protocol and pilot / C. McCarthyet et al. Implementation Science. 2017. Vol. 12. P. 99.

DOI: https://doi.org/10.1186/s13012-017-0629-1

27. The Ariadne principles: how to handle multimorbidity in primary care consultations / C. Muthet et al. BMC Medicine. 2014. Vol. 12. P. 223. DOI: https://doi.org/10.1186/s12916-014-0223-1

28. The effect of telehealth, telephone support or usual care on quality of life, mortality and healthcare utilization in elderly high-risk patients with multiple chronic conditions. A prospective study / B. Valdivieso et al. Medicina clinica. 2018. Vol. 151, No. 8. P. 308-314. DOI: https://doi.org/10.1016/j.medcli.2018.03.013

29. Using the Methodology of Systematic Review of Reviews for Evidence-Based Medicine / E. Hasanpoor et al. Ethiop J Health Sci. 2019. Vol. 29, No. 6. P. 775-778. DOI: https://doi.org/10.4314/ejhs.v29i6.15

30. Vital directions for health and health care: priorities from a National Academy of Medicine in itiative / V. J. Dzauet et al. JAMA. 2017. Vol. 317, No. 14. P. 1461-1470.

DOI: https://doi.org/10.1001/jama.2017.1964

31. What are the effective elements in patient-centered and multimorbidity care? A scoping review / M. Poitras et al. BMC Health Services Research. 2018. Vol. 18. P. 446. DOI: https://doi.org/10.1186/s12913-018-3213-8

Стаття надійшла до редакції 06.04 .2020 